\title{
Beyond disability as weakness: Perspectives from students with disabilities
}

\author{
Westley James, Caroline Bustamante, Kamryn Lamons, and Jacquelyn J. Chini \\ Physics Department, University of Central Florida, Orlando, FL, 32816
}

\begin{abstract}
Little research in physics education has explored the experiences of postsecondary students with disabilities (SWDs). Perspectives on disability vary in the extent to which they locate disability within the individual or within society. We conducted interviews with SWDs to explore their perspectives on disability and their experiences in STEM-specific courses. Using interpretative phenomenological analysis, we identified how the participants' experiences of impairment impacted their learning, often resulting in use of accommodations, such as extra test time. While accommodations allowed the participants to demonstrate content mastery, accommodation use also made them susceptible to disability stigma from peers and instructors who held an individual view of disability. Participants expressed that these feelings of stigma led them to value confidentiality. We argue that instructors who hold a social perspective of disability are in a better position to address barriers in the learning environment and to support SWDs.
\end{abstract}

\section{INTRODUCTION}

While students with disabilities (SWDs) make up $11 \%$ of the college student population [1], SWDs report that instructors lack awareness of how to support them [2]. Instructors also self-report feelings of uncertainty in supporting and interacting with SWDs due to a lack of training [3]. As physics education researchers who support instructors, it is imperative that we listen to and reflect on the experiences of SWDs to identify supportive and harmful classroom practices. However, little research has been done in this area [4]. In this paper, we present viewpoints and experiences expressed by three students with cognitive disabilities about their disability and accommodation use in higher education to illustrate multiple perspectives on disability and the role of the instructor in creating a supportive or harmful classroom culture.

Perspectives on disability vary in the extent to which they situate disability within the individual or within society. As Goodley explains, "Disability is a sociocultural phenomenon and a personal, embodied, physiological or psychological one" (pg. 1) [5]. For example, the moral model of disability posits that "disability is a defect caused by a moral lapse or sin", and the medical model posits that "disability is a medical problem that resides in the individual" (pg. 7) [5]. Both models focus on impairment (a functional limitation within the individual) as the cause of disability; while medical and technological advances motivated by the medical model have improved the lives of some people with disabilities, individual perspectives result in a model where disability is a personal deficit to be fixed, cured, or addressed through individual adjustment. On the other hand, social perspectives posit that "social, cultural, historical, economic, relational and political factors disable people" through physical and social barriers (pg. 9) [5]. The social model focuses on disablism (treating people with disabilities as Other or outside the able-bodied norm [6]) over impairments and promotes actions to remove barriers and increase accessibility. This perspective can promote integration of disability into a person's identity, but also requires strong self-advocacy skills and neglects the effect of impairment on everyday life. The extent to which students and instructors hold individual and social perspectives of disability will shape how SWDs are viewed and supported.

In this paper we explore the influences, consequences, and implications that impairment and societal structures have had on the lived experiences of SWDs in STEM courses. We then offer recommendations for instructors to better support SWDs.

\section{METHODS AND ANALYSIS}

We recruited students with executive function disorders (EFDs) for interviews about their experiences in college, especially in STEM courses. EFDs are characterized by difficulties with cognitive processes such as planning, problem solving, giving attention to tasks, and committing items to memory [7]. We recruited students from introductory physics and chemistry courses who were registered with the university's accessibility services office through emails from the office, as well as students who were not registered via emails from the course instructors. We recruited a total of fourteen students across three semesters who each participated in two one-hour semi-structured interviews. An additional student participated in four interviews across two semesters.

For this paper, we purposefully sampled three students based on the following criteria: 1) they talked extensively about their disability or their interactions with others concerning their disability; 2) they collectively represented multiple disability diagnoses; and 3) they were collectively diagnosed at differing stages of life. Albert (all names are pseudonyms) was diagnosed with dyslexia at age 8 . Bob was diagnosed with ADHD at age 20. Cloe did not identify her diagnosis or age of diagnoses; she participated in four interviews. Potential limitations of this sample are that students could only participate if they were comfortable identifying with EFD to the interviewer and all participants come from the same university. 
We designed the interviews based on research questions about the participants' college learning experiences, but participants also shared perspectives and experiences tied to their disability and accommodation use. All interviews were conducted by a graduate student researcher.

We chose to use interpretive phenomenological analysis (IPA) as we are external researchers trying to understand perspectives and experiences that are not our own [8]. IPA is a bottom up methodology that follows traditional phenomenological goals to understand an individual's perception of an experience, but differs in its recognition that the researcher must interpret these perceptions. The researcher aims to take the side of the participant and see the event from their perspective, but also goes further, seeking to make connections across participants and in relation to previous research. Our implementation of IPA followed these steps for each transcript: 1) familiarize ourselves with the transcripts by reading them multiple times; 2) generate comments paraphrasing relevant portions of transcript; 3) convert comments into emerging themes; and 4) develop factors to group themes. Researchers then look across participants' factors, identifying the major themes and the similarities and differences participants expressed within these themes. Finally, a narrative is generated that interprets these themes and the connections across them.

Three researchers conducted the primary analysis. The researchers cover a spectrum of disability diagnoses, including "able-bodied", undiagnosed, and diagnosed. The researchers include undergraduate and graduate students, with one undergraduate researcher pursing a non-physics, STEM degree. This diversity supported generation of multiple interpretations due to the unique perspective through which each researcher viewed the participants' responses.

TABLE 1 . Themes and subthemes with supporting quotes and interpretations
These researchers worked collaboratively in identifying, choosing, and interpreting the themes. To prepare for this, the graduate student trained the second and third researchers independently on using IPA. This was done by practicing the first three steps of IPA on an individual transcript (not one of the three participants presented in this paper). Emphasis was placed on only focusing on turns of speech where the participant explicitly connected an experience with their disability or accommodation use. Researchers were also encouraged to express and defend their interpretations of dialogue, and norms were established that every researcher's interpretations were of equal merit. If a disagreement occurred, it was discussed until the three researchers reached agreement. The researchers independently read through the transcripts for familiarity, and then generated comments and converted comments into emerging themes together. Finally, the researchers collaborated to identify the themes that were most important for each participant, as indicated by the extent to which it was talked about, the frequency mentioned without prompt, and the extent of its impact on the participant's life. The researchers then collaborated to interpret these themes and how the participants related or differed across them.

Table 1 shows the themes and subthemes, along with the supporting quotes and their interpretations. Quotes are identified in parenthesis as either aligning with the individual or social perspective of disability. Below, we discuss the themes which include: 1) impairment and the learning environment; 2) extra test time; and 3) interactions with others. We conclude with a discussion about how the individual and social perspectives expressed influence how SWDs are viewed and supported in higher education.

\begin{tabular}{|c|c|c|}
\hline Themes & Sub-themes & Quotes (individual/social perspective) \\
\hline \multirow[t]{3}{*}{$\begin{array}{l}\text { Impairment } \\
\text { and the } \\
\text { learning } \\
\text { environment }\end{array}$} & Impairment & $\begin{array}{l}\text { - "So, I have a specific learning disability. Which, and } \\
\text { specifically, I guess, issues with reading"(individual) - Albert } \\
\text { - "I like to learn things through reading, I just don't like the } \\
\text { reading itself." - Albert } \\
\text { - "so I'm understanding why I love order and structure so } \\
\text { much is because I don't have it and within, within my cognitive } \\
\text { processes. So when I have it in an exterior fashion, it's like, it's } \\
\text { like this is how I wish my brain would be. But it's not, so I have } \\
\text { it on paper" (individual) - Bob }\end{array}$ \\
\hline & $\begin{array}{l}\text { (Dis)abling } \\
\text { course features }\end{array}$ & $\begin{array}{l}\text { - "whatever sort of teaching stuff professors are using now I've } \\
\text { had to deal with in the past, the past ten years or more. So, I'm } \\
\text { pretty, I'm pretty much used to it and able to think, deal with } \\
\text { any issues that come up." - Albert } \\
\text { - "I would really prefer for him [the instructor's]... } \\
\text { organization in his powerpoints to be a lot better" (social) - } \\
\text { Bob }\end{array}$ \\
\hline & $\begin{array}{l}\text { Supportive } \\
\text { course features }\end{array}$ & $\begin{array}{l}\text { - "I've had classes that somehow manage to work with just no } \\
\text { lectures, no powerpoints, uh, some hands-on stuff, no textbook } \\
\text { learning, no reading, and we still manage to learn things, and I } \\
\text { have no idea how" (social) - Albert }\end{array}$ \\
\hline
\end{tabular}

Interpretations

Impairment linked with disability diagnosis

Course features introduce barriers specific to difficulties associated with impairments

Course features can remove difficulties associated with impairments 
TABLE 1. Continued

\begin{tabular}{|c|c|c|c|}
\hline Themes & Sub-themes & Quotes (individual/social perspective) & Interpretations \\
\hline \multirow[t]{2}{*}{$\begin{array}{l}\text { Impairment } \\
\text { and the } \\
\text { learning } \\
\text { environment } \\
\text { (contd.) }\end{array}$} & $\begin{array}{l}\text { Supportive } \\
\text { course features } \\
\text { (contd.) }\end{array}$ & $\begin{array}{l}\text { - "yeah actually, I really enjoyed it (supportive class)." - Albert } \\
\text { - "It was ah, just presented - I guess the information was kind of } \\
\text { hidden instead of just here it is so that we still learned it but } \\
\text { weren't specifically paying attention to these facts, these facts, } \\
\text { these facts, writing them out on note cards, remember them and } \\
\text { so forth..." - Albert } \\
\text { - "if you know at this time this week...there's going to be an } \\
\text { assignment due for this chapter, you know, okay, I can plan out } \\
\text { everything following up to that." - Bob }\end{array}$ & $\begin{array}{l}\text { Course features can } \\
\text { support strategies } \\
\text { individuals have } \\
\text { deemed valuable }\end{array}$ \\
\hline & $\begin{array}{l}\text { Test time } \\
\text { concerns }\end{array}$ & $\begin{array}{l}\text { - "It was always the amount of time I had to take the test, and } \\
\text { not even, I wouldn't not even say just that, it was, it was seeing } \\
\text { other people walk up and leave before me because that's where } \\
\text { the anxiety kicks in, that's where I'm like 'oh man I should have } \\
\text { finished by now'..." (individual) - Bob }\end{array}$ & $\begin{array}{l}\text { Traditional test time } \\
\text { insufficient and } \\
\text { introduces stress and } \\
\text { anxiety }\end{array}$ \\
\hline \multirow[t]{3}{*}{$\begin{array}{l}\text { Extra test } \\
\text { time }\end{array}$} & Use & $\begin{array}{l}\text { - "Yeah, not doing it [signing up for extra test time] is one less } \\
\text { thing to do." - Albert } \\
\text { - "I asked him [instructor] about it [providing extra test time for } \\
\text { quiz], but he didn't put it" (social) - Cloe }\end{array}$ & $\begin{array}{l}\text { Effort required and } \\
\text { instructor inhibitions } \\
\text { are barriers to extra } \\
\text { test time use }\end{array}$ \\
\hline & Value & $\begin{array}{l}\text { - "I think it's [extra test time] interacted uh in in one main } \\
\text { factor, the reduced stress that I have from the exam, from the } \\
\text { test taking. Now I don't have to worry about this, I only have to } \\
\text { worry about the material" (social) - Bob }\end{array}$ & $\begin{array}{l}\text { Extra test time } \\
\text { reduces stress and } \\
\text { anxiety caused by } \\
\text { time concerns }\end{array}$ \\
\hline & Confidentiality & $\begin{array}{l}\text { - "he would just say, like, in front of all the students, he would } \\
\text { just say like 'oh are you still going to like the [accessibility } \\
\text { services office] or at the testing center' and it's just like, 'wow, } \\
\text { professor', like this is supposed to be confidential, and you're } \\
\text { just like saying it in front of everybody" - Cloe } \\
\text { - "But now, they're [classmates] getting the trend because if it } \\
\text { was someone that you always sit with in the same class every } \\
\text { day, they're gonna know, 'Why don't you show up on the test } \\
\text { day?" - Cloe }\end{array}$ & $\begin{array}{l}\text { Confidentiality } \\
\text { valued, but risked by } \\
\text { instructors and } \\
\text { accommodation use }\end{array}$ \\
\hline \multirow[t]{5}{*}{$\begin{array}{l}\text { Interactions } \\
\text { with others }\end{array}$} & $\begin{array}{l}\text { Extra test time } \\
\text { "unfair" }\end{array}$ & $\begin{array}{l}\text { - "I don't want... everybody to know, they'll start judging...they } \\
\text { will be like 'oh, the only reason that she's getting a good grade } \\
\text { is 'cause she has extra time.' So I don't need them... them } \\
\text { thinking that." - Cloe } \\
\text { - "No, because ... Well, it depends, because if I come in they're } \\
\text { gonna be like, "Oh my god, she missed the quiz," and then } \\
\text { they'll be like, "Oh, yeah," like I can't, I'm not gonna tell them } \\
\text { that I already took it..." - Cloe }\end{array}$ & $\begin{array}{l}\text { Perception from } \\
\text { others that extra test } \\
\text { time gives unfair } \\
\text { advantage } \\
\text { Perception } \\
\text { discourages extra test } \\
\text { time use }\end{array}$ \\
\hline & & $\begin{array}{l}\text { - “...we're supposed to be...leveling the playing field. So like, } \\
\text { the same time that you [other students] get is adequate for...the } \\
\text { same time I get" (social) - Cloe }\end{array}$ & $\begin{array}{l}\text { Self-perception that } \\
\text { extra test time } \\
\text { provides equity }\end{array}$ \\
\hline & $\begin{array}{l}\text { Disability } \\
\text { stigma }\end{array}$ & $\begin{array}{l}\text { - "He [the instructor] thinks that 'Oh, because she's strong in } \\
\text { the subject, she wouldn't have a disability. She doesn't need } \\
\text { accommodations.' So the fact that he found out, he was like 'I'm } \\
\text { so shocked, like.' I guess he was being like biased or } \\
\text { stereotypical" (individual) - Cloe }\end{array}$ & $\begin{array}{l}\text { Perception from } \\
\text { others that disability } \\
\text { equals low } \\
\text { performance }\end{array}$ \\
\hline & $\begin{array}{l}\text { Positive } \\
\text { instructors }\end{array}$ & $\begin{array}{l}\text { - "he's a sweet guy and I can just tell from his lectures, very kind } \\
\text { hearted, very easy going. For with him it was very easy to talk } \\
\text { to about these things [accommodation use]." - Bob }\end{array}$ & $\begin{array}{l}\text { Instructor empathy } \\
\text { increases comfort }\end{array}$ \\
\hline & & $\begin{array}{l}\text { - "When they mention [accessibility services office] in class, it } \\
\text { makes them, it makes you feel like they're on your side, you } \\
\text { know?" - Cloe }\end{array}$ & $\begin{array}{l}\text { Highlighting } \\
\text { accommodations by } \\
\text { instructor encourages } \\
\text { their use }\end{array}$ \\
\hline
\end{tabular}




\section{IMPAIRMENT AND THE LEARNING ENVIRONMENT}

Albert and Bob both articulate impairments that they associate to their diagnosis. These impairments interact with the learning environment, and both identify how the traditional learning environment can both introduce and reduce barriers specific to their impairment. Barriers were reduced not by focusing on the individual, but rather on how the class is taught and structured.

Every participant expressed that time-constrained tests were a barrier to demonstrating their mastery of course material, resulting in anxiety about finishing on time. These feelings could be amplified by observing others finishing before them. Not only has test anxiety been shown to negatively impact course performance, but it also can result in lowered self-esteem, fears of negative evaluation, defensiveness and other forms of anxiety [9]. No teacher practices reduced this barrier, so participants made use of the extra test time accommodation.

\section{EXTRA TEST TIME}

The participants described the importance of extra test time in allowing them to fully demonstrate their content mastery and reducing test anxiety and stress. Its use varied across participants, with Cloe using it in every course and Albert and Bob only using it in some courses. The most significant barrier to use was professors who did not allow it, which does not meet the legal obligations of the Americans with Disabilities Act and also creates an unwelcoming and unsupportive classroom culture [9].

Access to accommodations requires that the instructor is notified of the student's identity and their allowed accommodations by the university's accessibility services office. Unless otherwise specified by a student, it is important for instructors to be mindful of maintaining confidentiality and not taking actions that could jeopardize it. Supportive practices that help maintain confidentiality include only discussing accommodations with students in settings away from other students or by changing seating assignments on test days to reduce the chance peers will notice the individual's absence.

\section{INTERACTIONS WITH OTHERS}

The value of confidentiality stemmed from feelings of judgement by or alienation from their instructors and peers. These feelings are characteristic of disability stigma, which in postsecondary settings can be associated with inaccurate assessments of a students' ability to complete college level work and inappropriate judgements by peers. This fear of stigma resulted in accommodations not being used, which has been found in prior research [11]. Practices to support confidentiality were discussed in the previous section, but instructors should also make statements encouraging the use of accommodations and the equity they provide.

\section{INDIVIDUAL AND SOCIAL PERSPECTIVES}

Within the quotes selected for this paper, each participant demonstrated both individual and social perspectives of disability. Statements that aligned with an individual perspective include Albert and Bob's description of their impairments, and Cloe's experience with an instructor whose view located deficit with the SWD. In several instances, the individual perspective produced disability stigma, either felt personally by the participant or expressed by an instructor. The participants demonstrated a social perspective by identifying classroom practices that removed or created barriers for them. Thus, we advocate instructors adopt a social perspective which increases accessibility and reduces stigma by placing the burden of change on our courses.

Universal Design for Learning is a promising framework that adopts the social perspective to help instructors plan for variation in students' skills, needs and interests [12]. However instructors must also recognize that until society is fully accessible we must provide and encourage equity through such means as accommodations. Likewise, until SWDs no longer experience stigma about disability and accommodation use, it is imperative that confidentiality is respected and maintained.

\section{ACKNOWLEDGEMENTS}

This work is supported by NSF DUE No. 1612009. Thank you to Erin Scanlon for feedback.
[1] T. D. Snyder, C. de Brey, and S. A. Dillow, Natl. Cent. Educ. Stat. (2016).

[2] R. D. Black, L. A. Weinberg, and M. G. Brodwin, Except. Educ. Int. 25, 1 (2015).

[3] J. L. Sniatecki, H. B. Perry, and L. H. Snell, 17 (n.d.).

[4] L. Frazer, ArXiv171007863 Phys. (2017).

[5] D. Goodley, Disability Studies: An Interdisciplinary Introduction (SAGE, 2016).

[6] D. Goodley, B. Hughes, and L. Davis, Disability and Social Theory: New Developments and Directions (Palgrave Macmillan, 2012).
[7] M. B. Denckla, in Exec. Funct. Educ. Theory Pract. (Guilford Press, New York, NY, US, 2007), pp. 5-18.

[8] J. A. Smith and M. Osborn, Qual. Psychol. Pract. Guide Res. Methods 25 (2015).

[9] R. Hembree, Rev. Educ. Res. 58, 47 (1988).

[10] Americans with Disabilities Act (1990).

[11] J. Trammell, J. Postsecond. Educ. Disabil. 22, 106 (2009).

[12] D. H. Rose, W. S. Harbour, C. S. Johnston, S. G. Daley, and L. Abarbanell, J. Postsecond. Educ. Disabil. 19, 135 (2006). 